\title{
Verbond en vergewing: Deuteronomium 29 en 30 en die deuteronomistiese geskiedwerk
}

\author{
HF van Rooy \\ Potchefstroomse Universiteit vir Christelike Hoër Onderwys
}

\begin{abstract}
Covenant and forgiveness: Deuteronomy 29 and 30 and the deuteronomistic history

The deuteronomistic history was written to illustrate to the Babylonian exiles that the judgement that had befallen them, was a just one. It does, however, also proclaim the possibility of forgiveness within the framework of the convenant. This is also the message of Deuteronomy 29 and 30 . This paper investigates this message of covenant and forgiveness in Deuteronomy 29 and 30 and its relationship to the deuteronomistic history.
\end{abstract}

\section{INLEIDING}

'n Verband tussen Deuteronomium en die boeke Josua, Rigters, Samuel en Konings word baie algemeen aanvaar. Dit kom veral daarop neer dat die basiese gedagterigting van Deuteronomium weerklank vind in die geskiedskrywing van Israel soos dit sy neerslag vind in hierdie groot geskiedeniswerk wat 'n oorsig bied van die geskiedenis van Israel sedert die intog in die beloofde land tot die Babiloniese ballingskap. Hierin kan daar iets van 'n volksondergang, 'n volksdood, gesien word. Die geskiedwerk toon aan hoe die volk ondergegaan het op grond van die voltrekking van God se oordeel. Indien die geskiedwerk sy afsluiting gekry het in die ballingskap, is dit duidelik dat die finale skrywer(s) daardeur 'n boodskap wil gee vir die volk van daardie tyd. Dit bied inderdaad ' $n$ besondere invalshoek vir die bestudering van die geskiedwerk. Indien dit alles saam bedoel is om 'n boodskap vir 'n sekere tyd weer te gee, dan word die geskiedenis van die intog, of van Dawid, of van Salomo, of van die ondergang van die twee ryke nie weergegee as geskiedenis as sodanig nie, maar as sake waaruit 'n 
boodskap moet spreek vir die mense van 'n besondere tyd. Weens die ooglopende band tussen die boodskap van Deuteronomium en die beoordeling van Israel se geskiedenis in die boeke Josua tot Konings, het die benaming deuteronomistiese geskiedwerk daarvoor algemene ingang gevind en word dit ook hier gebruik as 'n maklike benaming vir die geheel van die boeke (vir 'n navorsingsoorsig oor die verband tussen Deuteronomium en die deuteronomistiese Geskiedwerk vlg Preuss 1982: 20-26). Natuurlik moet dit aanvaar word dat daar in die samestelling van die deuteronomistiese geskiedwerk van bronne gebruik gemaak is. ' $n$ Voorbeeld hiervan is die sogenaamde troonopvolgingsgeskiedenis (ongeveer 2 Sam 7-20, 1 Kon 1 en 2), wat waarskynlik oorspronklik dateer uit 'n periode nie lank na die tyd van Salomo nie en wat later opgeneem is (en verwerk is) in die groter geskiedwerk. Ook oor die grense van die deuteronomistiese geskiedwerk en die eintlike Deuteronomium bestaan daar verskille. So het Noth (1957: 14, 40) Deuteronomium 1-4 (en 31-34) as deel van die geskiedwerk beskou en die eintlike Deuteronomium beperk tot Deuteronomium 5-30 (1957: $14,40)$. Van hierdie sake sal later weer aandag kry. Die doel hiervan is om te kyk na die plek van Deuteronomium 29 en 30 in Deuteronomium self en die moontlike verhouding met die deuteronomistiese geskiedwerk, veral toegespits op die saak van verbond en vergewing. Hiervoor sal eerstens die plasing van Deuteronomium 29 en 30 in die boek bekyk word met die plek van verbond en vergewing daarin, vervolgens sal aandag gegee word aan die struktuur en inhoud van die twee hoofstukke en ten slotte sal die saak van verbond en vergewing in die deuteronomistiese geskiedwerk aandag kry.

\section{DEUTERONOMIUM EN DIE PLEK VAN DEUTERONOMIUM 29 EN 30}

Oor die samestelling van Deuteronomium in sy huidige vorm bestaan daar groot meningsverskil onder geleerdes. Dit is onmoontlik om hier op alle besonderhede in te gaan, sodat daar slegs gekonsentreer word op die plasing van Deuteronomium 29 en 30 in die geheel. ' $n$ Ouer indeling het uitgegaan van die gedagte dat die wette die sentrale gedeelte van die boek vorm, met $1-11$ as inleiding en $27-34$ as slotgedeelte (Welch 1924: 20, 21, 174, 175; 1932: 8, 167, 202 en Eissfeldt $1954 / 5 ; 1964$ : 308). Soms word die slotgedeelte egter in twee onderafdelings verdeel, naamlik 27-30 en 31-34 (byvoorbeeld Weiser 1964: 
126v). Hoofstukke 27-30 word dan beskou as 'n slotrede van Moses en 31-34 as 'n historiese aanhangsel. Noth $(1957: 14,40)$ het $5-30$ as die eintlike Deuteronomium beskou. Von Rad (1958: 34; 1968: 8) vind in Deuteronomium 'n struktuur wat verband hou met ' $n$ verbondshernuwingsfees, met vier dele waarvan $27-30$ te doen het met seën en vloek. Kline (1972: 133) verbind ook 27-30, maar sien in die geheel van Deuteronomium 'n verbondstruktuur, waarin 27-30 te doen het met die bekragtiging van die verbond. Craigie (1976: 24) se uiteensetting stem met die van Von Rad ooreen, behalwe dat hy 31-34 ook aan die verbondstruktuur verbind.

Sommige wil 29-30 wel as 'n grootheid op sy eie benader. Hölscher beskou $29-30$ as 'n slotrede van Moses wat volg op drie redes van Moses $(1-4,5,6-11)$ en die wette $(12-26,28)$ en ' $n$ tussengedeelte (27). Hy beskou 31-34 as latere byvoeging (1922: 163-225). Hiermee hou Wright (1953: 314v, 329v) en Driver (1973: i-iii) se indelings wel verband. Hulle beskou $1-4$ as die eerste rede van Moses, 5-26 en 28 as ' $n$ tweede rede met 27 as ' $n$ tussengedeelte, $29-30$ as ' $n$ derde rede en 31-34 as aanhangsels. Lohfink se analise, gebaseer op die opskrifte in 1: 1, 4: 44, 28: 69 (MT, Afrikaans 29:1) en 33: 1, deel die boek in vier dele, 1: 1-4: 43, 4: 44-28: 68, 28: 69-32: 52 en 33: 1-34: 12 (1962: $32-34)$. Hy verbind dus 29 en 30 met 31 en 32 tot 'n eenheid.

Uit hierdie bespreking is dit in elk geval duidelik dat daar nie eenstemmigheid bestaan oor die plasing van 29 en 30 in die boek Deuteronomium nie. Daar is basies vier standpunte, waarin onderskeidelik 27-34 verbind word, 27-30 verbind word (met 31-34 of as aanhangsel of as volgende element in ' $n$ opset wat die hele boek tot eenheid verbind), 29-30 op sy eie as aparte rede van Moses beskou word of 29-32 verbind word. Standpuntname hieroor is belangrik vir die voortgang van hierdie bespreking, sonder om maar net bloot verskillende standpunte teen mekaar af te speel.

Deuteronomium bied homself grotendeels aan as 'n aantal redes van Moses gerig tot die volk voor die intog in die beloofde land. Die boek bestaan dus uit ' $n$ aantal toesprake van Moses aangevul deur stof van digterlike (byvoorbeeld die lied van Moses (Deut 32: 1-43)), historiese (byvoorbeeld die gedeelte van die vrystede (Deut 4: 41-43)) of redaksionele (byvoorbeeld die verskillende redaksionele opskrifte) aard. Veral laasgenoemde is van groot belang vir die struktuur van die boek. Dit kan beskou word as die redaksionele bindmateriaal waarmee die boek tot ' $n$ eenheid saamgevoeg word. Die twee grootste opskrifte word aangetref aan die begin van die boek (1: $1-5)$ en net na die historiese, 
inleidende gedeelte (4: 44-5: 1a). Deuteronomium 28: 69 (Afrikaans 29: 1) kan beskou word as 'n onderskrif wat Deuteronomium 1-28 as 'n eenheid saambind (vergelyk Van Rooy 1977/8: 169 vir 'n vollediger bespreking hiervan). Daar moet daarop gelet word dat verdere opskrifte in die gedeelte baie skaars is. In Deuteronomium 2: 10-12, 20-23 word wel korter historiese gegewens gegee en so ook in 4: 41-43. Daar kom alleen drie kleiner opskrifte in Deuteronomium 27 voor, 'n gedeelte wat meermale as ' $n$ tussengedeelte in die groter eenheid beskou is. Deuteronomium 29 en 30 word deur 'n aparte inleiding ingelei (29: 1a MT, 29: 2a Afrikaans). Vanaf hoofstuk 31 word 'n groter hoeveelheid klein opskrifte of ander redaksionele materiaal aangetref: $31: 1,7 \mathrm{a}, 9,10 \mathrm{a}, 14 \mathrm{a}$, 14c, 15, 16a, 22, 23a, 24, 25 en 30; 32: 44-46a, 48; 33: 1, 2a; 34: 1-4a, 5-12. Hieruit kan afgelei word dat Deuteronomium 1-28 die eintlike kern van die boek vorm, met 29-30'n groter aanhangsel en 31-34'n aanhangsel bestaande uit ' $n$ verskeidenheid van stof.

Deuteronomium 29 en 30 vorm dus 'n grootheid op sy eie. 'n Belangrike vraag is of die gedeelte wel verband hou - en hoedanig - met die voorafgaande kern van die boek. Die sleutel hiertoe lê in die uitdrukking hbryt $h z^{\prime} t$ wat in 29: 8 en 13 (MT) voorkom en wat direk teruggryp op die slotskrif in 28: 69 (MT). 'Hierdie verbond' word hier as bekend veronderstel en kan niks anders wees as die verbond waarna aan die begin van 28: 69 (MT) verwys word nie. Hieruit volg dat die twee hoofstukke iets wil sê oor die verbond wat in die groot eerste gedeelte van Deuteronomium weergegee word. Daardie gedeelte is dan die verbond in Moab, wat eintlik geld as 'n vernuwing of hernuwing van die verbond wat God met die volk te Horeb gesluit het. In Deuteronomium 29 en 30 word daarna teruggegryp om meer inligting rakende die verbond te gee.

\section{OORTREDING EN VERGEWING IN DEUTERONOMIUM}

In die prediking van Deuteronomium neem die vermaning om aan God gehoorsaam te wees, ' $n$ besondere plek in. Die hele styl van Deuteronomium kan inerdaad pareneties genoem word (Von Rad 1975: 220). Die sentrale boodskap van die vermanings word gerig teen die agtergrond van die gevaar dat Israel in sy roeping kan faal (Von Rad 1975: 223). Die basis van die vermaning tot gehoorsaamheid bly God se liefde. Omdat God steeds getrou was en is, moet die volk as antwoord aan Hom gehoorsaam wees. Die gevaar is juis dat die volk dit nie sal doen nie (Von Rad 1975: 225). Die gehoorsaamheid word steeds 
gefundeer op God se genade (Braulik 1982: 135). Die seëninge waarvan telkens sprake is, is die vrug van genade en gehoorsaamheid (Braulik 1982: 136). Gehoorsaamheid word nooit 'n voorvereiste tot verkiesing nie (Von Rad 1975: 229).

Oortreding van God se eise word telkens verbind aan straf as die gevolg daarvan. Dit word aangetref in die historiese inleiding, soos in Deuteronomium 1: 22-45, waar die volk se onwil om die land in te trek na die terugkeer van die verspieders verbind word aan God se oordeel in die veertig jaar in die woestyn. Toe was daar selfs nie vergewing vir die wat om genade gevra het nie. (1: 45-46). In die vermanings aan die einde van die historiese gedeelte, in Deuteronomium 4, word die saak van oordeel en straf na sonde ook onderstreep. Ongehoorsaamheid en ondergang gaan hand aan hand. Onder die oordele word ballingskap pertinent vermeld (4: $26-28)$.

Die basiese tema van ' $n$ oproep tot gehoorsaamheid verbind aan ' $n$ belofte van genade kom telkens voor in die vermanende gedeeltes in Deuteronomium 6-11. Dit word meermale ook gestel teen die teëpool, dat ongehoorsaamheid oordeel tot gevolg het, soos byvoorbeeld in Deuteronomium 11: 13-15 teenoor 11: 16-18. Kernagtig word die twee pole saamgevat in 11: $26-28$, naby die einde van die groot vermanende gedeeltes van die wetkorpus. Die volk word duidelik voor die keuse gestel: Gehoorsaamheid en seën gaan saam en ongehoorsaamheid en vloek. Hierdie basiese vermaning kom meermale ingevleg tussen die wette voor (byvoorbeeld 12: $25,28,32 ; 13: 4,18 ; 15: 4-6$ ) en die wetkorpus sluit weer met so 'n vermaning af (26: 16-19). Die seëninge en vloeke in Deuteronomium 27 en 28 hou duidelik ook hiermee verband. Oortreding en oordeel gaan saam.

Die enigste gedeelte in Deuteronomium 1-28 waar die moontlikheid van genade na die oordeel aan die orde kom, is in Deuteronomium 4: 29-31. Dit word voorafgegaan deur ' $n$ verwysing na ballingskap as oordeel (Deut 4: 26-28). Wat dan vereis word, is opregte gebed, heelhartige toenadering tot God, bekering (omkering, terugkeer) en gehoorsaamheid. Hierop sal genade volg, gebaseer op die verbond met die voorvaders. Hierdie verbond met die aartsvaders word sonder voorwaardes gestel en is blywend. Tog tree die vloeke van Sinai in werking wanneer die bepalings oortree word. Daarom word daar tot bekering opgeroep en wanneer bekering kom, tree daar nie 'n nuwe verbond na vore nie, maar die verbond by Sinai word dan weer herstel (vgl Schenker 1980: 96). Dit moet natuurlik steeds in gedagte gehou word dat die inhoud van die boek Deuteronomium - wat ' $n$ lang 
ontstaansgeskiedenis gehad het - nie net in een historiese situasie gespreek het nie (vgl Von Rad 1961: 5). In hierdie sin bly dit 'n boek wat staan tussen belofte en vervulling (Von Rad 1961: 7).

In die gedeelte na Deuteronomium 29 en 30 word die basiese oproep tot gehoorsaamheid ook telkens aangetref (byvoorbeeld 31: 12, 13 en in 32: 44-47, as slot na die lied van Moses). Die oordeel oor ongehoorsaamheid word ook duidelik uitgespel, soos in die lied van Moses (32: 15-35). Die lied word juis aangebied as deel van 'n ernstige waarskuwing aan die volk, waarin die gevolge van ongehoorsaamheid baie duidelik gestel word. Dit word baie duidelik gestel in 31: 16-18, waar die oordeel uitgespel word - ook ballingskap - en waarin selfs gesê word dat God Hom daarin vir sy volk sal verberg. Van genade is daar nie sprake nie.

\section{DIE STRUKTUUR EN INHOUD VAN DEUTERONOMIUM 29 EN 30}

Ten opsigte van die twee hoofstukke was daar reeds verskeie pogings om die struktuur van die twee hoofstukke aan 'n verdragspatroon te verbind. Een so 'n poging is die van McCarthy (1978: 199-205) waarin hy die gedeelte breedvoerig bespreek. Hy beskou dit ook nie as 'n deel van die eintlike Deuteronomium nie, maar dit hou wel daarmee verband. Die gedeelte is natuurlik nie 'n verdragsdokument nie, maar ' $n$ toespraak waarin getrouheid aan die Here vereis word. Tog kan elemente van die verdragsvorm in die twee hoofstukke raakgesien word. Hy verbind Deuteronomium 28: 69 aan die twee daaropvolgende hoofstukke en gee die volgende samevatting van die struktuur van die gedeelte (1978: 202 - die indeling volgens die MT):

28: $69 \quad$ Toneelskikking (mise en scene)

29: $1 \mathrm{~b}-8$ Historiese proloog

29: 9-14 Lys van partye betrokke by die verbond

29: 15-18 Bepaling

29: 19-27 Vloek

30: $1-10$ Seën

30: 11-14 Vermaning

30: 15-19 Seën en vloek

30: $19 \quad$ Getuies

30: $19 b-20$ Vermaning

Dit is ' $n$ rede met retoriese middele en al, maar die struktuur en 
elemente plaas dit in die verbondstradisie (McCarthy 1978: 202). Tog bied die ontleding sekere probleme, wat maak dat dit nie ' $n$ suiwer weergawe van ' $n$ verbondstruktuur kan wees nie. So sien McCarthy (1978: 200) 29: 9-14 as ' $n$ aanduiding van die partye betrokke by die verbond. Wanneer so ' $n$ aanduiding van die betrokke partye egter voorkom in die verdrae, of in gedeeltes wat die verdragstruktuur vertoon, is dit altyd deel van die inleiding. Selfs die voorbeeld wat McCarthy aanhaal om sy standpunt te staaf, kan nie daarvoor gebruik word nie. Hy verwys na die Sefire-verdrae, waar sowel sy $A$ as $B$ van Sefire I' $n$ inleiding het waarin die betrokke partye vermeld word. Daar word die partye in twee inleidings vermeld op heel formele wyse - die verdrag tussen $X$ en $Y$. Hier word die partye vermeld as deel van ' $n$ rede en hier in die besonder as deel van 'n uitnodiging om tot die verbond toe te tree.

'n Volgende probleem is die saak van die bepalings. McCarthy vind die bepalings in 29: 15-18 (MT). Tog word daarin nie 'n bepaling aangetref nie, selfs nie eers die basiese verbondsverpligting van gehoorsaamheid nie (McCarthy 1978: 200). Daar is 'n verwysing na vroeëre afvalligheid en ' $n$ vermaning teen toekomstige afvalligheid. Die hele gedeelte is ' $n$ vermaning gegrond op die sogenaamde Hauptgebot, maar dit bied nie self die Hauptgebot nie. Dat die gedeelte ten nouste met die verbond verband hou, staan vas en dat daar daarom sake kan voorkom wat met die verbondstruktuur verband hou, is te verwagte. Tog is dit nie ' $n$ verbondsteks as sodanig nie.

'n Baie belangrike studie oor onder andere Deuteronomium 29 en 30 is die van Lohfink (1962). Hy beskou Deuteronomium 28: 69-32: 47 as 'n eenheid wat te doen het met die verbondsluiting in die land van Moab. Hy sluit in die verband by Baltzer (1960) aan. Baltzer het in die twee hoofstukke duidelike elemente van sy Bundesformular aangetref. Hy noem pertinent die Historiese proloog (Vorgeschichte), 29: 1-7, Hoofgebod, (Grundsatzerklärung - 29: 8, 12 en 17), vloek en seën in 'n eksiliese uitbreiding (29: 21-30: 10), seën- en vloekformule (30: 16-18) en die aanroeping van hemel en aarde as getuies (30: 19). Lohfink beskou hierdie vorm as die sleutel vir die verstaan van Deuteronomium 29 en 30 (1962: 30). Hy onderskei ses onderafdelings in die gedeelte, wat dan soos volg saamgestel is (1962: 43):

Historiese proloog (29: 1-8)

Protokol (verslag) van die verbondsluiting (29: 9-14)

Waarskuwende prediking (29: 15-20) 
Afsluitende vloekgedeelte en seëninge in eksiliese uitbreiding (29: 21-30: 10)

Bevelende prediking (30: 11-14)

Seën, vloek, getuies en slotwaarskuwing (30: 15-20).

Alhoewel die verdragstruktuur vir hom die sleutel bied vir die verstaan van die gedeelte, wil hy dit nie in sy oorspronklike vorm as sodanig beskou as die basis waarop die gedeelte se struktuur gebou is nie. Sy motivering is dat sowel die hoofgebod as die besondere bepalings ontbreek (1962: 43). Die vraag is dan of daardie vorm dan werklik as sleutel vir die verstaan van die gedeelte kan dien as dit wat die wesentlike kern van die vorm is, ontbreek. Lohfink wil verder die vorm van die twee hoofstukke aan 'n kultiese vorm verbind $(1962: 43,44)$. Die verbondstruktuur wil hy dan sien as 'n vorm vir'n dokument, wat dan 'n verbandhoudende kultiese vorm kon gehad het. Tog moes die vorm in aanpassing vir die kultus sekere veranderinge ondergaan het. $\mathrm{Hy}$ sien die basiese vorm vir die kultus soos volg (1962: 44):

Voordrag van die historiese proloog

Verkondiging van die verbondsluiting

Prediking

Seën, vloek, aanroeping van getuies en slotvermaning.

Die geheel van die twee hoofstukke hou dan vir hom verband met 'n verbondsluitingseremonie. Van die vier elemente van die veronderstelde kultiese seremonie stem ook wel ooreen met dele van sy struktuur van die twee hoofstukke, soos die historiese proloog ( 1 by albei), die verbondsluiting self ( 2 by albei), prediking ( 3 by die seremonie en 3 en 5 by Deut 29 en 30) en die seën, vloek, aanroeping van getuies en slotvermaning ( 4 en 6 onderskeidelik). Hoe punt 4 van die twee hoofstukke egter met die seremonie verbind word, makk hy nie duidelik nie. Tog is die gedagte van ' $n$ verbondsluitingseremonie en die verbinding van die twee hoofstukke daaraan, baie aanloklik. Ook Braulik (1970: 43-44) wil die gedeelte aan 'n seremonie verbind, maar dan 'n eedseremonie waarin die volk by wyse van ' $n$ eed die verpligtinge op hulleself neem. Voordat ' $n$ finale oordeel gevel kan word, moet die struktuur van die twee hoofstukke egter weer goed beskou word. Vir die struktuur van die twee hoofstukke is daar sekere uitstaande struktuurmerkers waaraan aandag gegee moet word. By Deuteronomium 29 is die verwysing volgens die MT. Na die inleiding van 29: 1 word daar drie keer aan die begin van onderafdelings die 
selfstandige persoonlike voornaamwoord ' $t m$ vooropgestel aangetref. Twee keer (29: $1 b, 15)$ word daarna nog 'n werkwoord in die perfektum aangetref $\left(r^{\prime} y \mathrm{tm}, y d^{c} t m\right)$. Daar word die volk dus gewys op sekere kennis wat hulle het en wat van belang is vir die saak waarom dit gaan. Die saak wat die kern van die gedeelte vorm, word tussen die twee dele aangetref, na die 'tm nșbym hywm aan die begin van 29: 9. Sowel Lohfink as McCarthy beskou 29: 1-20 as bestaande uit minstens drie gedeeltes. Albei sien 1-8 as 'n historiese proloog. Albei beskou 9-14 as ' $n$ afsonderlik deel, die protokol van die verbondsluiting (Lohfink) of die lys van betrokke partye. Lohfink beskou 15-20 as waarskuwende prediking en McCarthy sien in 15-18 die hoofgebod. Tog wys die merkers dat die drie dele 'n eenheid vorm met $9-14$ as die kern, dit waaroor die vandag gaan. 29: 1-8 bied hiervoor 'n toneelskikking met historiese gegewens. Daarin word kortliks 'n oorsig gegee wat inhoudelik ' $n$ opsomming is van Deuteronomium 1-3. 29: 9-14 bevat 'n oproep op die volk om tot die verbond toe te tree en die bepalinge daarvan na te kom. Die bepalinge word nie vermeld nie, maar veronderstel. Veral die verwysing na $h b r y t h z^{\prime} t$ - wat hier veral na bepalinge verwys - en wat moet verwys na 28: 69 (as afsluiting van Deut 1-28) maak dit duidelik dat die bepalinge waarom dit hier gaan, die bepalinge is van Deuteronomium 1-28 (en 12-26 in besonder). In hierdie verbond is die kinders, die geslagte wat nog kom, ingesluit. Die gedeelte 29: 15-20 sluit weer aan by die voorafgedeelte deurdat dit vir die aanwesiges ' $n$ vermaning bring tot gehoorsaamheid en getrouheid aan God. Die belang van die aanwesiges blyk uit die hywm wat in 29: 17 aangetref word. Oor hulle word daar 'n vloek ('n oordeel) uitgespreek as hulle ontrou word. Die vloek word nader bepaal as die vloek wat in hierdie boek opgeteken is (29: $\left.19 h^{\prime} l h h k t w b h b s p r h z h\right)$. Dit is verbondsvloeke wat deel maak van die wetboek (29: 20). Die boek waarna verwys word, word nie in die voorafgaande gedeelte van Deuteronomium 29 vermeld nie, maar word duidelik as bekend veronderstel, soos blyk uit die aanwysende byvoeglike naamwoord $h z h$. Dit kan alleen ' $n$ verwysing wees na Deuteronomium 28: 58 en 61. In die eerste geval is daar sprake van 'hierdie boek' en in die tweede van 'die boek van hierdie wet', met sterk tekskritiese steun vir 'n lesing 'hierdie wetboek'.

Die eerste gedeelte van Deuteronomium $29(29: 1-20)$ is dus baie sterk gerig tot die aanwesiges, wat die verbond aanvaar en wat daaraan getrou moet bly. Die gedeelte sluit ook sterk aan by die sentrale boodskap van Deuteronomium, met die eis tot verbondsgehoorsaam 
heid. Gehoorsaamheid en voorspoed word verbind (vers 8 ) en ookongehoorsaamheid en oordeel (15-20). Die aansluiting met die voorafgaande word ondersteun deur die verwysing na 'hierdie wetboek'.

In die volgende gedeelte word die blik na die toekoms verskuif, met 'n verwisseling van onderwerp. Die nuwe onderwerp word in vers 22 ingelei as hdr h'hrwn, wat tog aan die huidige geslag verbind word met die apposisie bnykm. Die gedeelte sluit af met ' $n$ algemene stelling in 29: 28. Uit die inhoud van die gedeelte blyk dit dat kronologies wel volg op 29: 1-20. Tog gryp dit ook terug na Deuteronomium 1-28 en veral weer na die vloeke wat daarin opgenoem word. Dit blyk veral uit 29: 26, waar qllh gebruik word as aanduiding van die vloek, anders as in 29: $1-10$, waar 'lwt vyf keer voorkom. qllh kom ook voor in Deuteronomium 28: 15, 45 en nog ses keer in Deuteronomium 1-28. Ook die verwysing na hspr hzh (29: 26) gryp terug na Deuteronomium 1-28, soos ook die verwysing na htwrh hz't in 29: 28 . Die slotvers van die gedeelte (29: 28) vorm eintlik ' $n$ afsluiting vir die hele hoofstuk. Dit plaas die verpligting om die verpligtinge na te kom, vierkantig op die volk se skouers. Die volk word in die hoofstuk ook grotendeels aangespreek in die tweede persoon meervoud of na verwys in die derde persoon meervoud. Die uitsondering is die persoonlike voornaamwoordelike suffiks tweede persoon enkelvoud, wat twee maal voorkom in vers 4 en elf maal in verse 10-12. In die gedeelte $29: 21-28$ word wel na die toekomstige geslag verwys, maar dit is veral bedoel om die teenwoordiges op die gevolge van ongehoorsaamheid te wys.

Aan die begin van Deuteronomium 30 begin daar weer 'n nuwe gedeelte, met die tydsaanduiding whyh ky. Dat 'n nuwe gedeelte hier begin, kan ook gesien word daaraan dat die volk in die enkelvoud aangespreek word. Die vorme van die tweede persoon enkelvoud word konsekwent gebruik in 30:1-17. Eers in vers 18 word daar weer tweede persoon meervoudsvorme gebruik. Daarvan word drie in vers 18 aangetref, opgevolg deur een enkelvoudsvorm. In vers 19 word een meervoudsvorm aan die begin aangetref, gevolg deur vier enkelvoudsvorme. In vers 20 word weer net meervoudsvorme aangetref. Alhoewel daar dus in 30: 1 'n nuwe gedeelte begin, is daar tog 'n verband met die voorafgaande. Deuteronomium 29 het geëindig met God se oordeel, waaronder heel aan die einde ballingskap eintlik terloops vermeld word. In die eerste gedeelte van Deuteronomium 30 is ballingskap die agtergrond vir dit wat gesê word. Daarin word gesê wat die volk in 
ballingskap sou moes doen om weer genade te kry. Die gedeelte gryp ook terug na Deuteronomium 1-28. Dit blyk uit die uitdrukking $k l$-hdbrym h'lh aan die begin van die gedeelte. Hierdie uitdrukking of uitdrukkings soos ' $l$ h hdbrym word meermale in Deuteronomium 1-28 gebruik om die inhoud van die verbond (bepalings, seëninge en vloeke) aan te dui. Dit word byvoorbeeld aangetref in die inleiding tot Deuteronomium 1-28 (1: 1) en in die slot (28: 69). Vergelyk ook 4: 30; $6: 6 ; 27: 3,8 ; 28: 14,58$. Die verbinding met Deuteronomium 1-28 blyk ook uit die woorde wat gebruik word om dbrym hier nader te omskryf: brkh wqllh. Die twee woorde word ook in hierdie verbinding aangetref in 11: 26 en daarna afsonderlik omskryf in 11: 27 en 28 en saam vermeld in 11: 29. Die twee woorde is ook saam 'n samevatting van die inhoud van Deuteronomium 28. Die gedeelte strek tot by 30: 10 en is vir die saak van verbond en vergewing van die grootste belang.

In 30: 11 begin 'n nuwe gedeelte met 'n nuwe onderwerp, hmşwh. Die gedeelte gryp hiermee ook terug na Deuteronomium 1-28, waar mșwh meermale kollektief gebruik word as aanduiding van die geheel van die inhoud van die verpligtinge wat die volk opgelê is - vergelyk 8: $1 ; 11$ : $8 ; 15: 5 ; 19: 9$ (waar selfs dieselfde betreklike bysin as hier gebruik word om die mșwh te omskryf - hmșwh 'šr 'nky mșwk hywm) en 11: 22 en 27: 1 (waar die betreklike bysin effens verskil). In die gedeelte word die aard van die gebod uitgespel en dit is weer gerig tot die aanwesiges self.

In Deuteronomium 30: 15 begin 'n laaste gedeelte, ingelei met die imperatief $r$ ' $h$. Die gedeelte is 'n slotoproep waarin die volk aangespoor word om die verbond te onderhou, om duidelik stelling in te neem. Onderhouding bring seën en ongehoorsaamaheid vloek. brkh en qllh word hier langs mekaar gestel (30: 19) en verbind aan lewe en dood. Ook die gedeelte is spesifiek gerig tot die teenwoordiges. Die struktuur van die twee hoofstukke sien dus soos volg daar uit:

1. Die verbondsluiting (29: $1-20)$

1.1 Historiese begronding (29: 1-8)

1.2 Die verbondsluiting self (29: 9-14)

1.3 Vermaning tot gehoorsaamheid (29: 15-20)

2. Die gevolge van ongehoorsaamheid (29: 21-28)

3. Berou en bekering in ballingskap (30: 1-10)

4. Aard van die gebod (30: 11-14

5. Vermaning tot die regte keuse (30: 15-20). 


\section{OORTREDING EN VERGEWING IN DEUTERONOMIUM 29 EN 30}

In die eerste gedeelte, 29: 1-20, word die volk opgeroep om tot die verbond toe te tree en vermaan om die bepalinge van die verbond na te kom. Daar is wel sprake van oortreding, maar met as noodwendige gevolg die vloek, die oordeel van God. Vergewing word in soveel woorde uitgesluit (29: $19-\mathrm{l}^{\prime} \mathrm{y}^{\prime}$ bh yhwh slh lw). Die persoon wat oortree se naam sal vernietig word en hy sal tot oordeel bestem word. Die verbondsvloeke is sy voorland (29: 19-20).

In die tweede gedeelte (29: $21-28$ ) word breedvoerig gewys op die gevolge van oortreding. Geweldige rampe sal die land tref as oordeel op verbondsverbreking (29: 24). In die verbondsboek is vloeke opgeskryf en dit sal in vervulling gaan na verbondsverbreking (29: 26). Balalingskap "tot op vandag" word in die vooruitsig gestel (29:27). Dit alles trek saam in die dringende vermaning dat al die woorde van die wet nagekom moet word (29: 28$)$ - sonder sprake van vergewing.

In die vierde gedeelte $(30: 11-14)$ word die aard van die wet uiteengesit as iets wat binne die mens se vermoë is om na te kom.

In die vyfde gedeelte (30: 15-20) word die keuse duidelik voor oë gestel: lewe of dood, gehoorsaamheid of ongehoorsaamheid. Gehoorsaamheid bring seën en 'n lang lewe in die beloofde land, ongehoorsaamheid bring vloek en ballingskap.

Dit is net in die derde gedeelte (30: 1-10) waar oortreding en vergewing verbind word en spesifiek vergewing in die ballingskap wat die volk as oordeel sal tref. Die gang van die oortreding en vergewing loop soos volg:

Oortreding (dit word veronderstel - vergelyk 29: 27)

Oordeel (wanneer al hierdie dinge oor jou kom - vs 1)

Besinning (wanneer jy tot nadenke kom - vs 1)

Bekering (wanneer jy terugkeer tot Jahwe - vs 2)

Gehoorsaamaheid in die ballingskap (wanneer jy na sy stem luister vs 2)

Verandering van omstandighede deur God (vs 3)

Genadebetoning en terugkeer uit ballingskap (vs 3ee5)

Verandering van die innerlike gesindheid deur God (vs 6)

Oordeel oor die vyande (vs 7)

Nuwe gehoorsaamheid en voortgaande seën (vs 8-10).

Wat hieruit afgelei kan word, is dat bekering na oortreding en oordeel, vergewing voorafgaan. Daardeur word die verhouding met God herstel 
en volg daarop die nuwe gehoorsaamheid en die voortgaande seën. In die versteurde verhouding het God 'n wending teweeggebring met as gevolg die feit dat God weer sorg vir die lewe van sy volk (Jepsen 1961: 264).

Hierdie gedeelte vertoon in meerdere opsigte ooreenkomste met Deuteronomium 4: 29-31, wat reeds bespreek is as die enigste ander gedeelte in Deuteronomium waar daar pertinent van vergewing na oordeel sprake is. Van die elemente hierbo vermeld, word die volgende ook daar aangetref:

1. Oortreding $(4: 25)$

2. Oordeel $(4: 26,27,30)$

4. Bekering (4: 30$)$

5. Gehoorsaamheid $(4: 30)$

7. Genadebetoning ( $4: 31)$

Daar is egter ook belangrike verskille, sodat 30 : $1-10$ nie bloot as 'n uitbreiding op daardie tema gesien kan word nie. In 30: 1 word gestel dat die volk tot besinning sal kom, iets wat in 4: 29-31 ontbreek. Ook ontbreek die spesifieke verwysing dat God die volk uit ballingskap sal terugbring asook enige verwysing na wat op die terugkeer sal volg. In 4: 29-31 word dus wel die moontlikheid van vergewing gestel, maar die besonderhede van wat op die vergewing sal volg, ontbreek.

Wat in die gedeelte besondere klem ontvang is dat die volk tot inkeer en omkeer moet kom. Vir Israel beteken die omkeer veral dat hulle weer die wet moet onderhou (Schenker 1980: 98). Hierop is Jahwe se antwoord dat Hy weer omkeer en aan die volk genade bewys. Die uitsig wat Deuteronomium 30: 1-10 op die geskiedenis bied gaan uit van drie stadia in die geskiedenis, naamlik seën aan die begin, afval en oordeel in die middel en omkeer en nuwe seën daarna (Schenker 1980: 100). Nuwe gehoorsaamheid aan die wet en die nuwe seën gaan hand aan hand. Hierdie gedeelte word baie algemeen in die ballingskap gedateer. Preuss stel dit dat die gedeelte die oordeel nie as die einde van die pad van Jahwe met die volk wil beskou nie, maar dat dit die moontlikheid en belofte van omkeer reflekteer (1982: 160-161).

\section{DIE BOODSKAP VAN DIE DEUTERONOMISTIESE GESKIEDWERK}

Alhoewel in die samestelling van Josua tot Konings van verskillende bronne gebruik gemaak is, vertoon die boeke tog 'n sekere eenheid 
(Ackroyd 1968: 64). Die finale verwerking van die werk het waarskynlik tydens die ballingskap plaasgevind, soos blyk uit die verwysing na die vrylating van Jojagin. Dit kan teen die middel van die sesde eeu vC gedateer word (vergelyk Wolff 1961: 172). Wolff sien as die basiese beginsel ten grondslag van die werk die siening dat die geskiedenis van Israel oor sewe eeue beskou word teen die agtergrond van die profetiese Godswoord, veral soos gestel in Deuteronomium (1961: 172). Die boodskap is dan gerig tot die ballinge. Hierdie boodskap wys op die oordeel van God wat die volk getref het weens hulle ongehoorsaamheid, maar wil tog ook aan die verwagting vashou dat die beloftes aan Dawid weer in vervulling sal gaan (Wolff 1961: 173). Wolff sien dan 'n patroon wat in die geskiedenis telkens weer voorkom, naamlik van die verband tussen afdwaling en straf (1961: 174). Vir vergewing is dit nodig dat die volk tot Jahwe roep, dat hulle hulle skuld bely, bid om verlossing en bereid moet wees tot 'n nuwe gehoorsaamheid (1961: 177). Wolff meen dat Deuteronomium 30: 1-10 van 'n tweede deuteronomistiese redaktor kom en dat daarin eintlik die werklike tema van die deuteronomistiese geskiedwerk gestel word in die mond van Moses (1961: 182). Wat gevra word in die deuteronomistiese geskiedwerk, is dat die volk hulle in die ballingskap opnuut in die gebed tot God sal rig, hulle sal bekeer en God gehoorsaam sal wees (1961: 183). 'n Belangrike patroon in die werk is die van opstand en vergewing, van oordeel en belofte (Ackroyd 1968: 75). Die volk moet die oordeel aanvaar as regverdig voordat daar 'n nuwe uitsig kan kom (Ackroyd 1968: 78). Die volk het deur hulle eie skuld die aanspraak op verlossing verbeur (Von Rad 1975: 342). Die volk het dit wat God hulle opgelê het, nie nagekom nie en die oordeel was die gevolg. Tog is daar in die ballingskap steeds gehoop op God se verbondenheid aan die volk, die verpligting wat $\mathrm{Hy}$ op Homself geneem het (vgl Freedman 1964: 430).

\section{VERGEWING NA OORTREDING IN DIE DEUTERONOMISTIESE GESKIEDWERK}

Indien aanvaar word dat 'n finale verwerking van die deuteronomistiese geskiedwerk tydens die ballingskap plaasgevind het, is ' $n$ belangrike vraag hoe die redakteur(s) hulle boodskap deur die boek tot die adres gerig het. Oor die vraag van die presiese adres bestaan daar wel meningsverskil, of dit die ballinge in Babilon was of die agtergeblewenes in Juda (vergelyk Ackroyd 1968: 65-68). Dit is egter 'n vraag wat op 
sy eie hanteer moet word. Wat die deuteronomistiese boodskap betref, is dit so dat van bronne gebruik gemaak is en dat van die bronne tot 'n mate selfs omlyn kan word met sy eie boodskap - soos byvoorbeeld die troonopvolgingsgeskiedenis (vergelyk Ackroyd 1968: 62 en Van Rooy 1986). Tog behoort die eie boodskap van die redakteur(s) apart onderskei te kan word.

Die belangrikste wyses waarop die boodskap kan kom, is die keuse van materiaal en redaksionele beoordelings en kommentaar (soos die deurlopende beoordelings van die konings van Juda en Israel). Daar is egter 'n verdere belangrike saak, naamlik die redaksionele verwerking van toesprake en gebede. In sulke sake kan daar relatief eenvoudig gedeeltes tydens redaksie ingevoeg word waaruit die boodskap van die redakteurs spreek (vgl ook Ackroyd 1968: 64).

Deel van die basiese boodskap van Deuteronomium en die deuteronomistiese geskiedwerk is die saak van gehoorsaamheid en seën en ongehoorsaamheid en oordeel. Hierdie deel van die boodskap van die deuteronomistiese geskiedwerk kom meermale na vore in die beoordelings van die konings. 'n Positiewe beoordeling is die een wat van koning Josia gegee word ( 2 Kon 23: 25): En soos hy was daar nie tevore 'n koning wat na Jahwe teruggekeer het met sy hele hart, sy hele siel en met sy hele vermoë, ooreenkomstig die hele wet van Moses nie en na hom sal daar nie een soos hy kom nie. 'n Negatiewe beoordeling word van Sedekia gegee (2 Kon 24: 19): Hy het gedoen wat verkeerd was in die oë van Jahwe, soos alles wat Jojakim gedoen het.

'n Goeie voorbeeld van ander redaksionele materiaal waarin die redaktor(s) se boodskap weergegee word, word aangetref in 2 Konings 17: 7-23, waarin 'n beoordeling gegee word van die redes wat tot die ondergang, vernietiging en ballingskap van die noordelike ryk gelei het. In die gedeelte word die sondes van die volk duidelik uitgespel aan die begin (7-12). Daarna word dit gestel dat God die volk gewaarsku het en opgeroep het tot bekering en gehoorsaamheid (13). Die volk het hierdie vermaning egter voortdurend verontagsaam en van kwaad na erger gegaan (14-17). Dit het uitgeloop op oordeel oor Israel (18-23). Deel van die oordeel was die skeuring van die ryk (21) en in die noordelike ryk is ' $n$ pad tot ondergang gevolg wat op ballingskap 'tot vandag toe' gelei het (23).

Wat die keuse van materiaal betref, is dit meermale duidelik dat slegs dit gebruik word wat ten dienste van die boodskap aangewend kan word. Die bekendste voorbeeld in die verband is Omri wat ver buite Israel bekend was, maar van wie in 1 Konings 16 weinig gesê word 
behalwe die beoordeling wat van hom gegee word as 'n koning wat gedoen het wat verkeerd is in die oë van die Here.

Wat van die belangrike redes in die deuteronomistiese geskiedwerk betref, is dit natuurlik te verwagte dat die basiese tema van gehoorsaamheid en seën besondere aandag sal kry. Dit is byvoorbeeld die kern van die boodskap wat God in Josua 1: 1-9 tot Josua rig. Josua word baie sterk vermaan om die wet van Moses sorgvuldig na te kom. Daar is 'n spesifieke verwysing na die spr htwrh (8), met 'n belofte van voorspoed aan gehoorsaamheid verbind. Hierdie basiese tema is ook die inhoud van die vermaning wat Josua gerig het tot die stamme wie se erfdeel oos van die Jordaan was (Jos 22: 1-6). Hier is 'n verwysing na die mswh en twrh wat Moses die volk beveel het (5). Josua het die stamme dan ook geseën (6). Hierdie patroon wat in Josua se woorde voorkom, kom ook voor in die seën wat Salomo oor die volk uitgespreek het na die inwyding van die tempel (1 Kon 8: 54-61).

Hierdie basiese positiewe boodskap word dikwels aangevul met die negatiewe keersy dat ongehoorsaamheid sal uitloop op oordeel, waaronder ballingskap soms pertinent ingesluit word. Dit kom voor in Josua se afskeidswoorde by twee geleenthede - soos wat Deuteronomium 29 en 30 ook aangebied word as deel van die afskeidswoorde van Moses. In Josua 23 word die volk eers herinner aan God se groot dade (1-5). Daarna word die volk opgeroep tot gehoorsaamheid aan alles wat geskryf is in die wetboek van Moses (6). Hierdie opdrag word breedvoerig gestel $(6-11)$, met dan 'n aanduiding van die teëpool, van oordeel (12-13). Die volk het God se genade ervaar (14), maar as hulle ongehoorsaam is, sal hulle ook die oordeel ervaar (15-16). Verbondsbreuk en ballingskap word pertinent verbind (16).

Hierdie patroon herhaal hom ook basies in Josua se rede tydens die byeenkoms in Sigem (Josua 24). Daar is ook eers ' $n$ herinnering aan God se groot dade in die geskiedenis $(1-13)$ opgevolg deur 'n oproep tot gehoorsaamheid (14). Daarna word die volk tot standpuntinname gedwing (15-22). Die volk word na hulle standpuntinname opgeroep tot gehoorsaamheid (23), waarop hulle positief antwoord (24). Die oordeel word duidelik aan hulle voorgehou (20).

Ook in die afskeidsrede van Samuel (1 Sam 12), word die volk tot gehoorsaamheid opgeroep, na 'n historiese gedeelte waarin melding gemaak word van vorige gevalle van oordeel, straf, inkeer en vergewing (tydens die rigtertyd - 8-12). Seën en gehoorsaamheid en oordeel en ongehoorsaamheid word dan teenoor mekaar gestel (13-15).

In God se antwoord op Salomo se gebed by die inwyding van die 
tempel word die verbinding van gehoorsaamheid en seën en ongehoorsaamheid en oordeel weer aangetref (1 Kon 9: 4-5, 6-9). Ondergang, die vernietiging van die tempel en ballingskap word uitdruklik vermeld. Ook in die aankondiging van die rykskeuring word sonde en oordeel verbind (1 Kon 11: 9-13).

Die moontlikheid van vergewing na bekering nadat God se oordeel voltrek is, word meermale vermeld, soms in 'n kort opmerking en soms breër uitgewerk. ' $n$ Korter opmerking word aangetref in 1 Samuel 3: 7 waar die volk opgeroep word tot bekering voordat God hulle van die Filistyne sou verlos. Ook in 2 Konings 17: 13, waarna reeds verwys is, word die oproep tot bekering aangetref. Josia se bekering en smart oor die volk se sondes word in 2 Konings 22 : $18-20$ verbind aan die uitstel van die voltrekking van die oordeel.

Die saak van vergewing na oortreding kom egter die duidelikste na vore in Salomo se gebed na die inwyding van die tempel (1 Kon 8: 22-53). Die verband van die gebed met Deuteronomium kan gesien word aan die woorde waarmee Jahwe aan die begin van die gebed aangespreek word: Jahwe, God van Israel, daar is geen God soos U in die hemel daarbo of op die aarde hieronder nie, ( $U$ wat) die verbond en trou bewaar vir $\mathrm{u}$ knegte wat met hulle hele hart voor $\mathrm{u}$ wandel. Veral belangrik is die uitdrukking šmr hbryt whhsd, wat meermale in die inleiding van gebede voorkom (Dan 9: 4, Neh 1:5 en 9:31). In al hiwrdie gevalle moet die gebruiik van die uitdrukking gesien word teen die agtergrond van Deuteronomium 7: 9-12 (vergelyk Van Rooy 1982/3: $164-167)$. Daar word gestel dat God sy genade betoon aan die wat sy gebooie gehoorsaam maar dat Hy sy haters straf. Die oordele wat in die gebed vermeld word, kan ook almal aangetoon word in die vloeke in Deuteronomium 28.

In die gebed van Salomo word daar vir verskillende sake gebid. In vier gevalle word daar spesifiek gebid om vergewing (1 Kon 8: 33-34, $35-36,37-40$ en 46-51). Alhoewel die vier bedes nie 'n identiese patroon vertoon nie, is daar tog sekere basiese elemente, soos sonde, oordeel, bekering, vergewing en genade. Die basiese patroon word kortliks aangetref in 8: 33-34, met die volgende elemente: sonde, oordeel, bekering (šwb), belydenis, gebed, vra om genade, versoek dat God luister, die sondes vergeet en terugkeer uit ballingskap bewerkstellig. Dit is merkwaardig dat laasgenoemde hier gevra word terwyl ballingskap as oordeel nie vroeër in die gebed vermeld word nie. In 8: 46-51 word eintlik dieselfde basiese patroon as hierbo aangetref, net meer uitgebreid. Hier word ballingskap uitdruklik genoem as deel van 
die oordeel. Skuldbelydenis kom hier pertinent aan die orde. Wat verder merkwaardig is, is die feit dat vergewing gevra word, maar nie terugkeer uit die ballingskap nie - wel genade by hulle gevangenemers.

\section{GEVOLGTREKKING}

Alhoewel vergewing na oortreding wel in die deuteronomistiese geskiedwerk sy plek het, wil dit tog voorkom asof dit nie die kern van die boodskap is nie. Dit bly ondergeskik aan die beoordeling van die geskiedenis van die volk as 'n geskiedenis van ongehoorsaamheid wat op 'n regverdige oordeel uitgeloop het (vgl ook Ackroyd 1968: 78). Voordat daar sprake van vergewing kan wees, moet daar by die volk die duidelike besef kom dat die oordeel verdien is en moet daar 'n hartgrondige bekering kom. Eers daarna is daar die moontlikheid van vergewing wat op herstel kan uitloop. In hierdie opsig kan die plek van vergewing na oortreding in die deuteronomistiese geskiedwerk vergelyk word met die plek van Deuteronomium 30: 1-10 in Deuteronomium 29 en 30. Dit is daar nie die kern van die boodskap vir die huidige geslag nie. Vir hulle is gehoorsaamheid aan die verbond die sentrale oproep. Dit is ook die boodskap vir die volk van die eksiliese tyd. Terugkeer na die land is ondergeskik aan bekering. So gesien is die deuteronomistiese geskiedwerk 'n stuk prediking, soos ook Deuteronomium 29 en 30. Daar word vermaan en bestraf, die oordeel word verklaar en as billik aangetoon. Die doel hiervan is ' $n$ oproep tot bekering. Alleen so kan daar seën wees, alleen so kan daar vergewing wees, alleen so kan die gebroke band herstel word - wanneer God ook sal optree om die volk innerlik te herstel (Deut 30:6). Vergewing is inderdaad 'n fundamentele vernuwing deur God bewerkstellig, 'n gawe van God waarin Hy self teenwoordig is (Gunneweg 1976: 12). So kan daar wel 'n verwagting wees dat God die verbond sal herstel in 'n nuwe verbond, waar die sondes vergewe en die wet op die hart geskryf sal staan (Jer 31: 33).

Die boodskap waarby die deuteronomistiese geskiedwerk op die ou end wel uitkom, is die boodskap van vergewing na bekering, dieselfde boodskap wat Deuteronomium 30: 1-10 binne die opset van Deuteronomium 29 en 30 verkondig. Dit is 'n boodskap wat vir die verstaan van sowel Deuteronomium as die geskiedwerk van die grootste belang is, want daardeur word ' $n$ perspektief tot 'n nuwe toekoms geopen te midde van die ellende van die ballingskap. 


\section{Literatuurverwysings}

ACKROYD, PR 1968. Exile and restoration. London: SCM.

BALTZER, K 1960. Das Bundesformular. Neukirchen: Neukirchener Verlag. (WMANT 41.) BRAULIK, G 1970. Die Ausdrücke för 'Gesetz' im Buch Deuteronomium. Biblica 51: 39-66.

BRAULIK, G 1982. Gesetz als Evangelium: Rechfertigung und Begnadigung nach der deuteronomistische Tora. ZThK 79: 126-160.

CRAIGIE, PC 1976. The book of Deuteronomy. Grand Rapids: Eerdmans. (NICOT.)

DRIVER, GR 1973. Deuteronomy. 3rd ed. Edinburgh: Clark. (ICC.)

EISSFELDT, O 1954/55. Die Umrahmung Des Mose-Liedes Dtn 32: 1-43 und MoseGesetzes Dtn 1-30 in Dtn 31: 9-32: 44. Wissenschaftliche Zeitschrift der Universität Halle 4: 411-417.

EISSFELDT, O 1964. Einleitung in das Alte Testament. 3. Aufl. Tubingen: Mohr.

FREEDMAN, DN 1964. Divine commitment and human obligation. Interp. 18: 417-431.

GUNNEWEG, AHJ 1976. Schuld ohne Vergebung? Evangelische Theologie 36: 2-14.

HÖLSCHER, G 1922. Komposition und Ursprung des Dt. ZAW 40: 161-255.

JEPSEN, A 1961. Gnade und Barmherzigkeit im Alten Testament. Kerygma und Dogma 7: $261-271$.

KLINE, MG 1972. The structure of Biblical authority. Grand Rapids: Eerdmans.

LOHFINK, N 1962. Der Bundesschluss im Lande Moab. Redaktionsgeschichtliches zu Deut 28: 68-32: 47. Biblische Zeitschrift 6: 32-56.

McCARTHY, DJ 1978. Treaty and covenant. 2nd ed. Rome: Biblical Institute Press. (Analecta Biblica 21A.)

NOTH, M 1957. Uberlieferungsgeschichtliche Studien. 2. Aufl. Tübingen: Max Niemeyer.

PREUSS, HD 1982. Deuteronomium. Darmstadt: Wissenschaftliche Buchgesellschaft. (Erträge der Forschung 164.)

SCHENKER, A 1980. Unwlderrufliche Umkehr und neuer Bund. Kerygma und Dogma 27: 93-106.

VAN ROOY, HF 1977/8. Structural analysis and exegesis: Illustrated with reference to Deuteronomy. OTWSA 20/1: 162-180.

VAN ROOY, HF 1982/3. bryt in Daniel. OTWSA 25/6: 163-174.

VAN ROOY, HF 1986. Nathan's promise and the succession history. OTWSA 27/8: $321-338$.

VON RAD, G 1958. Das formgeschichtliche Problem des Hexateuch, in Gesammelte Studien zum Alten testament, 9-86. München: Kaiser. (Theologische Bücherei 8.)

VON RAD, G 1968. Das fünfte Buch Mose. Deuteronomium. 2. Aufl. Göttingen: Vandenhoeck. (ATD).

VON RAD, G 1975. Old Testament theology, I. London: SCM.

WEISER, A 1964. The Old Testament: Its formulation and development. New York: Association Press.

WELCH, AC 1924. The code of Deutonomy. London: Clarke.

WELCH, AC 1932. Deuteronomy: The framework to the code. London: Oxford University press.

WOLFF, HW 1961. Das Kerygma des deuteronomistischen Geschichtswerks. ZAW 73: $171-186$.

WRIGHT, GE 1953. Deuteronomy, IB II: 311-330. 